\title{
ANALISIS ANTESEDEN YANG MEMPENGARUHI NIAT BELI ON-LINE PADA TOKOPEDIA.COM
}

\author{
Nur Rokhim \\ Rokhim6@gmail.com \\ Universitas Ahmad Dahlan \\ Fitroh Adhilla \\ fitauad@yahoo.com \\ Universitas Ahmad Dahlan
}

\begin{abstract}
ABSTRAK
This research was conducted to examine the antecedents that affect online purchase intentions. The sample used in this study amounted to 71 respondents. The sampling method using purposive sampling. Data analysis method used is quantitative analysis using validity and reliability tests, $\mathrm{F}$ tests, coefficient of determination, $\mathrm{t}$ tests and multiple regression analysis. By using the multiple regression method it can be concluded that the web design variable does not have a positive and significant effect on online purchase intention with a significance value ( $\mathrm{P}$ Value) of $0.324>0.05$. While reliability has a positive and significant effect on online purchase intentions with a significance value (P Value) of $0.018<0.05$. responsiveness has a positive and significant effect on online purchase intentions with a significance value (PValue) of $0.061>0.05$. The guarantee has a positive and significant effect on online purchase intention with a significance value (P Value) of 0.815>0.05. For ordering a positive and significant effect on online purchase intentions with a significance value ( $\mathrm{P}$ Value) of $0,002<0.05$. Simultaneously web design, reliability, responsiveness, guarantee, and ordering have a significant effect on online purchase intention with an $\mathrm{F}$ count of 5.960 with a significance value ( $\mathrm{P}$ Value) of $0.000<0.05$. The resulting determination coefficient is 0.246 , which means that 24.6 percent of changes in the online purchase intention variable are explained by changes in web design variables, reliability, responsiveness, guarantees, and bookings together, while the remaining 76.4 percent is explained by other variables which is not included in this study.
\end{abstract}

Keyword: Web design, reliability, responsiveness, guarantees, online ordering and purchase intentions.

\section{PENDAHULUAN}

Penerapan electronic commerce bermula di awal tahun 1970 an,dengan adanya inovasi semacam electronic fund transfer (EFT). Saat itu tingkat aplikasi masih terbatas pada perusahaan-perusahaan besar, lembaga keuangan, dan segelintir perusahaan kecil yang nekat. Lalu muncul electronic data interchange (EDI), yang berkembang dari transaksi keuangan ke pemprosesan transaksi lain serta memperbesar jumlah perusahaan yang berperan serta, mulai lembaga lembaga keuangan hingga perusahaan manufaktur, ritel layanan dan sebagainya. Aplikasi-aplikasi lain kemudian menyusul, yang memiliki jangkauan dari perdagangan saham hingga system reservasi perjalanan. Pada saat itu sistem tersebut disebut sebagai aplikasi telekomunikasi yang dinilai strategis sudah terkenal secara umum. Dengan adanya komersialisai internet diawal tahun 1990an, serta pesatnya pertumbuhan yang mencapai jutaan pelanggan potensial, maka muncullah istilah electronic 
commerce (e-commerce), yang aplikasinya segera berkembang pesat. Pusat riset e-comerce di Universitas Texas yang mempelajari 2000 perusahaan internet, sektor yang tumbuh paling cepat adalah e-comerce, yang naik sampai $72 \%$ dari $\$ 99,8$ milyar menjadi \$171,5 milyar. Pada tahun 2002 satu triliun dolar pendapatan dihasilkan dari internet.

Seiring dengan perkembangan zaman dan semakin pesatnya kemajuan pada dunia teknologi internet yang ada di Indonesia dan bahkan dari sebagian masyarakat Indonesia sudah menjadi gaya hidup hal ini tentu memberikan dampak bagi pola hidup manusia, Mereka tidak hanya membutuhkan dan menginginkan kebutuhan primer (makanan, pakaian dan tempat tinggal) saja, tetapi juga memberikan perhatian yang besar terhadap pemenuhan kebutuhan-kebutuhan sekunder dan tersier. Telepon genggam murah dengan fasilitas akses internet, biaya koneksi yang terjangkau, hingga status jejaring sosial yang marak menjadi salah satu contoh perkembangan teknologi informasi yang sangat signifikan pada saat ini.

Melalui internet pula dapat memasarkan produk dengan cara membuka toko tanpa ruang fisik dengan pangsa pasar yang luas khususnya di dalam penjualan barang-barang fashion seperti tas, baju, celana, jam tangan, sepatu, kerudung dan lain-lain. Dapat diperjual belikan secara mudah. termasuk pola interaksi jual-beli yang sudah memberikan banyak peluang bagi generasi muda untuk terjun dalam usaha jual beli melalui internet (ecommerce) atau biasa disebut dengan online shop.

Referensi data yang ada menjadi semakin menarik ketika kita menyadari bahwa 100 juta pengguna internet merupakan potensi pasar yang besar serta akan mempengaruhi munculnya berbagai peluang bisnis baru. para pelaku bisnis harus semakin jeli melihat peluang ini untuk memajukan bisnis. Maju atau tenggelam di era 100 juta pengguna internet.

Dari sekian banyak bermunculan situs jual beli online di indonesia diantaranya Lazada, Kaskus, Bukalapak, Bhineka, Agoda, Zalora, Lamido, BliBli, dan salah satunya Tokopedia adalah situs jual beli online sudah terparcaya di kehidupan masyarakat Indonesia baik yang hanya melihat iklan di televisi maupun yang sudah melakukanpembelian secara langsung. Tokopedia (www.tokopedia.com) hadir sebagai e-commerce baru yang inovatif dan mengusung konsep kumpulan berbagai toko online di Indonesia. Segala aktivitas jual beli dan proses transaksi akan dijamin keamanannya melalui perantaraan Tokopedia.

Konsep ini diharapkan dapat mewujudkan suatu bentuk mall online yang memprakarsai dan mengkoordinasi sejumlah transaksi e-commerce. Melihat uraian di atas didalam penelitian ini saya sebagai peneliti merasa tertarik untuk melakukan penelitian mengenai minat beli onlineuntuk situs online tokopedia.com dimana untuk referensi dalam penelitian saya menggunakan jurnal yang berjudul Exploring The Determinants Of retail service quality on the internet di dalam jurnal tersebut terdapat tujuh dimensi kualitas layanan yaitu tangibility, reliability, responsiveness, assurance, ordering, akan tetapi melihat hasil dari penelitian di atas untuk di terapkan dalam penelitian selanjutnya hanya diambil lima variabel kerena setelah memeriksa kembali masing-masing dimensi dan menghapus item berdasarkan SPSS direkomendasikan kriteria dan pemeriksaan pentingnya item untuk dimensi, alpha baru yang berkisar dari 0,58 untuk 0,83. Dimensi komunikasi memiliki alpha asli dari 0.0169 dan alpha direvisi dari 0.2714 dengan dua item yang tersisa dalam dimensi. Dengan demikian, dimensi komunikasi ditiadakan dari analisis lebih lanjut. 
Parasuraman et al. (1988) juga menghilangkan komunikasi dari skala akhir mereka. Dari semua, 22 item dihilangkan.

\section{Rumusan Masalah}

1. Apakah ada pengaruh secara parsial tangibility (desain web), reliability (keandalan), responsiveness (daya tanggap), assurance (jaminan), ordering (pemesanan) terhadap niat beli on-line pada tokopedia.com.?

2. Apakah ada pengaruh secara simultan tangibility (desain web), reliability (keandalan), responsiveness (daya tanggap), assurance (jaminan), ordering (pemesanan) terhadap niat beli on-line pada tokopedia.com.?

\section{REVIEW LITERATUR DAN HIPOTESIS}

\section{Landasan Teori}

\section{Pengertian E-Commerse}

Menurut Humdiana dan Idriyani (2005), e-commerce adalah pembelian dan penjualan, pemasaran pelayanan serta pengiriman dan pembayaran produk, jasa dan informasi jaringan di internet dan lainya antara perusahaan berjaringan dengan pelanggan, pemasok dan mitra

bisnis lainya.

Menurut Barkatullah dan Prasetyo (2005), e-commerce adalah kegiatan-kegiatan bisnis yang menyangkut konsumen (consumers), manufaktur (manufactures), service provider dan pedagang perantara (intermediaries), dengan menggunakan jaringan-jaringan komputer (computer networks) yaitu internet.

\section{Jenis-jenis E-Commerce}

Menurut Humdiana dan Idriyani (2005), Banyak perusahaan sekarang mensponsori tiga kategori dasar dari system e-commerce yaitu:

a) $\mathrm{B} 2 \mathrm{C}$ ( Business to Constemers)
Perusahaan harus mengembangkan pasar elektronik yang menarik untuk menjual berbagai produk dan jasa ke para pelanggan.

System e-commerce yang berfokus pada pelanggan memiliki tujuan penting yang sama yaitu menarik calon pembeli, melakukan transaksi atas barang dan jasa, serta membangun loyalitas pelanggan melalui pelayanan yang baik untuk setiap individu dan terlibat dengan berbagai fitur komunitas. Business to constemers memiliki karaktristik sebagai berikut (Raharjo, 2005)

b) B2B (Business to Business)

E-commerce B2B adalah sisi grosir yang di pasok dari proses komersial, tempat berbagai perusahaan untuk membeli, menjual atau berdagang dengan perusahaan-perusahaan lain (Raharjo, 2005).

\section{c) $\mathrm{C} 2 \mathrm{C}$ (Constemers to Constermers)}

Keberhasilan besar dari lelang on-line seperti e-bay, tempat para pelanggan dan juga perusahaan dapat membeli dan menjual satu sama lain dalam proses situs web lelang, menjadikan $\mathrm{C} 2 \mathrm{C}$ sebuah strategi bisnis ecommerce yang penting.

\section{Unsur-unsur bauran pemasaran situs online}

Ada beberapa unsur yang harus diperhatikan dalam melakukan pemasaran pada situs web:

a) Produk.

dapat dilihat dari jasa-jasa yang ditawarkan oleh berbagai situs dan cenderung dibedakan satu produk dan produk lain, serta mempunyai kelebihan di bidang masing-masing.

b) Harga.

Harga yang dimaksud adalah harga yang ditawarkan oleh pemilik situs web terhadap pemasang iklan dimana ia menjual produknya, buka bagi para pelanggan yang singgah.

c) Promosi. 
Promosi mengambil peran penting dalam hal ini. Biaya merupakan faktor utama untuk membuat situs menjadi terkenal.

d) Tempat.

Distribusi berarti dalam hal aliansi kepada provider yang menyediakan jaringan. Semakin banyak provider, semakin cepat akses ke pelanggan tercapai.

e) Orang.

Orang merupakan sumber daya manusia yang mengisi konten.

f) Proses.

Proses pemasaran produk harus berbasis teknologi informasi. Semuanya menggunakan proses teknologi.

g) Layanan pelanggan.

Yang termasuk dalam hal ini adalah kecepatan isi dari situs tersebut diperbarui dan dimutakhirkan.

\section{Penelitian Terdahulu}

Long and Charles McMellon (2004), "Exploring the determinants of retail service quality on the Internet, Journal of Services Marketing",dan memiliki hasil penelitian dengan pemeriksaan koefisien standar regresi untuk mengukur kualitas secara keseluruhan terdapat 7 variabel dengan 2 variabel empati, komunikasi menunjukkan hasil tidak berpengaruh sedangkan variabel lainnya menunjukkan bahwa tangibility/bukti fisik layanan (0.384) adalah komponen yang paling penting yang diikuti oleh proses pembelian (0.301), jaminan (0.203), responsif (0.103) dan kehandalan (0.080). Temuan ini menunjukkan bahwa skala baru berperilaku seperti yang diharapkan dalam kaitannya dengan konstruksi yang terkait.

\section{Hipotesis}

H1: Ada pengaruh secara parsial desain web, Keandalan, daya tanggap, jaminan, terhadap niat beli on-line pada tokopedia.com
H2: Ada pengaruh secara serempak desain web, Keandalan, daya tanggap, jaminan, terhadap niat beli on-line pada tokopedia.com.

\section{METODE PENELITIAN}

\section{Populasi dan Sampel}

Menurut Sugiyono (2013), populasi adalah wilayah generalisasi yang terdiri atas obyek/subyek yang mempunyai kualitas atau karaktristik tertentu yang ditempatkan oleh peneliti untuk dipelajari dan kemudian ditarik kesimpulan.

Menurut Sugiyono (2013), sempel adalah bagian dari jumlah dan karaktristik yang dimiliki oleh populasi tersebut. Bila populasi besar dan peneliti tidak mungkin mempelajari semua yang ada pada populasi, misalnya karena keterbatasan dana, tenaga, dan waktu, maka peneliti dapat menggunakan sempel yang diambil dari populasi itu. Apa yang dipelajari dari sempel itu, kesimpulanya akan dapat diberlakukan untuk populasi. Untuk itu sempel yang diambil dari populasi harus betul-betul representative (mewakili).

Menurut Sugiyono (2013), teknik sampling adalah merupakan teknik pengambilan sempel. Untuk menentukan sempel yang akan digunakan dalam penelitian, dan di dalam penelitian ini menggunakan teknik sampling nonprobability sampling yaitu teknik pengambilan sempel tidak memberi peluang/kesempatan yang sama bagi setiap unsur atau anggota populasi untuk dipilih menjadi sampel dan dengan menggunakan purposive sampling adalah teknik penentuan sempel dengan pertimbangan-pertimbangan tertentu yaitu sempel yang diambil dalam penelitian ini hanyalah seseorang yang pernah melihat web atau pernah membuka, melakukan pembelian pada situs online tokopedia.com dan usia 17 - 35 serta pendidikan minimal SMA kelas 1 sampai dengan $\mathrm{S} 1$. 
Cara dalam menentukan sampel bila dalam penelitian akan melakukan analisis multivariate (korelasi atau regresi berganda ) maka jumlah anggota sampel minimal 10 kali jumlah variabel yang diteliti yaitu jumlah variabelpenelitinya ada 6 (independen + dependen) maka jumlah anggota sampel dalam penelitian ini adalah $=6 \times 10=60$ jadi minimal sampel yang diambil untuk penelitian ini adalah 60.

\section{Definisi Operasional}

1. Variabel Independen

Menurut Umar (2003), variabel bebas adalah variabel yang mempengaruhi atau menjelaskan variabel yang lain. Variabel bebas dalam penelitian ini adalah desain web, keandalan, daya tanggap, jaminan, pemesanan.

2. Variabel Dependen

Menurut Umar (2003), variabel terikat adalah variabel yang dijelaskan atau dipengaruhi oleh variabel independen variabel terikat dalam penelitian ini adalah niat beli.

\section{Uji Instrumen}

\section{Uji Validitas}

Validitas suatu alat ukur adalah apakah suatu alat ukur dapat mengukur apa yang sebenarnya ingin diukur. Uji validitas perlu dilakukan untuk mengetahui sejauh mana suatu alatukur yang digunakan dalam penelitian dapat mengukur apa yang sebenarnya ingin peneliti ukur atau dapat digunakan untuk menguji instrumen penelitian agar instrumentersebut dapat memberikan hasil sesuai dengan tujuannya (Cooper dan Schindler, 2001).

Pengujian validitas yang dilakukan adalah construct validity dengan metode confirmatory factor analysis yang dilakukan dengan bantuan program SPSS. Analisis faktor digunakan dalam analisis penelitian ini karena merupakan salah satu metode statistik multivariate yang tujuan utamanya untuk meringkas atau mengurangi data atau variabel yang akan diperlukan untuk dianalisis.

Analisis faktor memecahkan masalah yang menyangkut hubungan timbal balik antara sejumlah indikator dan kemudian menjelaskan keterkaitan antar indikator ke dalam dimensidimensi yang mendasari hubungan tersebut. Karena item-item pertanyaan dalam kuisioner diadopsi dari penelitian sebelumnya dengan dimodifikasi maka analisis faktor yang dilakukan bersifat confirmatory, yaitu saat pengolahan pada tahap extraction dipilih number of factor adalah 6 sesuaidengan variabel yang diuji dalam model penelitian. Kriteria signifikansi terhadap item-item pertanyaan dalam penelitian ini didasarkan pada signifikansi praktis (practical significance) (Hair et al., 1998) seperti terlihat pada tabel 3.1 berikut:

\begin{tabular}{|l|l|}
\hline Faktor Loading & Keterangan \\
\hline Lebih besar dari 0.30 & Level minimal \\
\hline Lebih besar dari 0.40 & Sangat Penting \\
\hline Lebih besar dari 0.50 & Signifikan \\
\hline Sumber: Hair et al., 1998 & \\
\hline
\end{tabular}

2. Uji Reliabilitas

Uji reliabilitas untuk menguji ketepatan instrumen pengukur dengan konsistensi diantara butir-butir pernyataan dalam suatu instrumen. Reliabilitas berkaitan dengan ketepatan prosedur pengukuran dan konsistensi. Suatu alat ukur yang dinilai reliabel jika pengukur tersebut menunjukkan hasil-hasil yang konsisten dari waktu ke waktu.

Peneliti menguji instrumen penelitian dengan sampel sejumlah 30 responden. Koefisien reliabilitas ditunjukkan oleh koefisien cronbach Alpha yang berkisar antara 0 sampai 1. Semakin tinggi nilai koefisien 
cronbach alpha berarti semakin tinggi reliabilitas alat ukur yang digunakan. Untuk menguji reliabilitas dalam penelitian ini adalah dengan membandingkan cronbach coefficient alpha ( $\mathrm{r}$ Alpha) pada hasil olahan SPSS Release 13.0 dengan rule of thumb/kesepakatan umum dari koefisien alpha yaitu lebih besar dari 0,6 untuk penelitian eksploratori.

\section{Teknik Analisis Data}

1. Analisis Regresi Berganda

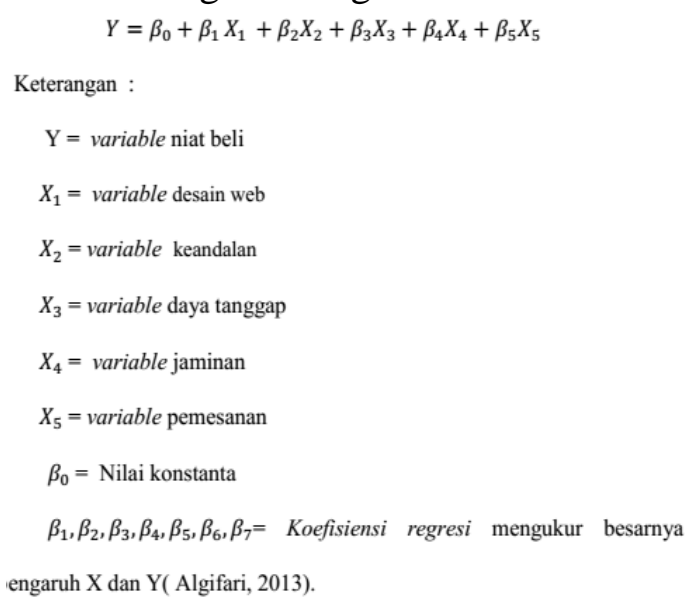

\section{Uji Hipotesis}

\section{Uji Parsial (Uji T)}

Uji signifikansi parsial atau individu digunakan untuk menguji suatu variabel bebas berpengaruh atau tidak terhadap variabel terikat. Pada regresi berganda mungkin variabel sampai $X$ yang terakhir secara bersama-sama berpengaruh nyata. Namun belum tentu secara individu atau parsial seluruh variabel dari sampai $\mathrm{X}$ terakhir berpengaruh nyata terhadap variabel terikatnya (Y).

2. Uji Simultan (Uji F)

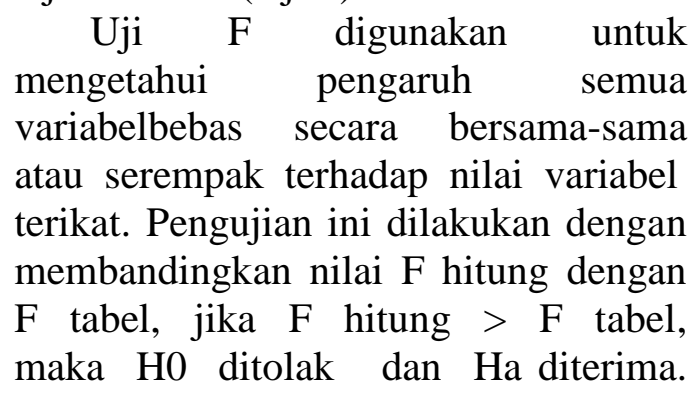

Artinya variabel bebas secara bersama-sama mempunyai pengaruh terhadap variabel terikat, dan jika $\mathrm{F}$ hitung < F tabel maka variabel bebas secara bersama-sama tidak mempunyai pengaruh terhadap variabel terikat.

3. Uji Koefisien Determinasi

Koefisien determinasi (R2) pada intinya mengukur seberapa jauh kemampuan sebuah model menerangkan variasi variabel dependen (Ghozali, 2005). Besarnya koefisien determinasi dari 0 sampai dengan 1. Semakin mendekati nol maka semakin kecil pula pengaruh semua variabel independen terhadap nilai variabel dependennya, begitu pula sebaliknya. Kelemahan dasar penggunaan koefisien determinasi ini adalah bisa terhadap jumlah variabel independen yang dimasukkan kedalam model. Setiap penambahan satu variabel independen, maka R2 pasti meningkat tidak peduli apakah variabel tersebut berpengaruh secara positif atau negatif terhadap variabel dependen. 


\section{HASIL PENELITIAN DAN PEMBAHASAN}

\section{Hasil Penelitian}

1. Hasil Uji Validitas

\begin{tabular}{|c|c|c|c|c|c|c|}
\hline \multirow[t]{2}{*}{ Indikator } & \multicolumn{3}{|r|}{ Komponen } & \multicolumn{3}{|l|}{ Faktor } \\
\hline & 1 & 2 & 3 & 4 & 5 & 6 \\
\hline $\mathrm{X} 1.1$ & 0.787 & & & & & \\
\hline $\mathrm{X} 1.11$ & 0.747 & & & & & \\
\hline $\mathrm{X} 1.12$ & 0.769 & & & & & \\
\hline $\mathrm{X} 1.13$ & 0.874 & & & & & \\
\hline $\mathrm{X} 2$ & & 0.791 & & & & \\
\hline $\mathrm{X} 2$ & & 0.716 & & & & \\
\hline $\mathrm{X} 2$ & & 0.757 & & & & \\
\hline $\mathrm{X} 2$ & & 0.719 & & & & \\
\hline $\mathrm{X} 3.1$ & & & 0.754 & & & \\
\hline $\mathrm{X} 3.2$ & & & 0.753 & & & \\
\hline $\mathrm{X} 3.3$ & & & 0.855 & & & \\
\hline $\mathrm{X} 3.4$ & & & 0.785 & & & \\
\hline $\mathrm{X} 3.6$ & & & 0.708 & & & \\
\hline $\mathrm{X} 4.1$ & & & & 0.772 & & \\
\hline $\mathrm{X} 4.2$ & & & & 0.778 & & \\
\hline $\mathrm{X} 4.3$ & & & & 0.783 & & \\
\hline $\mathrm{X} 4.7$ & & & & 0.695 & & \\
\hline X5.1 & & & & & 0.520 & \\
\hline $\mathrm{X} 5.2$ & & & & & 0.773 & \\
\hline $\mathrm{X} 5.3$ & & & & & 0.819 & \\
\hline X5.4 & & & & & 0.800 & \\
\hline $\begin{array}{r}\mathrm{X} 5.5 \\
\end{array}$ & & & & & 0.670 & \\
\hline Y.1 & & & & & & 0.752 \\
\hline Y.2 & & & & & & 0.651 \\
\hline Y.3 & & & & & & 0.615 \\
\hline Y.4 & & & & & & 0.784 \\
\hline Y.5 & & & & & & 0.760 \\
\hline
\end{tabular}

Dari tabel diatas dapat disimpulkan bagaimana telah disebutkan sebelumnya, bahwa dalam pengujian validitas dan realibilitas instrumenpenelitian menggunakan tryout terlebih dahulu terhadap 30 responden. Sedangkan dalam perhitungan, peneliti menggunakan bantuan komputer program SPSS release 16.00 for windows.

a) Uji validitas variable Tangibility $\mathrm{X} 1$

Tabel component matrix pada hasil output SPSS, terlihat bahwa terbentuk sebanyak 4 component, padahal yang diharapkan terbentuk hanya 1 component, artinya dari sepuluh indikator X1.1 s/d X1.13 tersebut ada yang tidak valid. jadi jika indikator-indikator tersebut valid, maka hanya akan membentuk satu faktor yakni desain web, oleh karena itu proses harus diulang dengan mengeluarkan indikator-indikato yang dianggap tidak valid Indikator-indikator yang akan dikeluarkan adalah indikator-indikator yang memiliki MSA (measure of sampling adequacy) yang di bawah 0,5, dengan memperhatikan tabel anti-images matrices pada output SPSS.

Perhatikan pada bagian antiimage correlation, terlihat bahwa indikator X1.10 memiliki $\mathrm{MSA}=0.354$, dengan demikian indikator tersebut dikeluarkan dari analisisTerlihat pada tabel component matrix, masih terbentuk sebanyak 4 factor, artinya diantara 12 indikator masih ada indikator yang menjelaskan faktor lain selain desain web oleh karena itu harus dikeluarkan lagi indikator yang memiliki MSA yang paling kecil (jika MSA yang dibawah 0,5 sudah habis, maka yang dikeluarkan adalah yang memiliki MSA terkecil). Terlihat pada bagian anti-images correlation bahwa indikator X1.6 memiliki MSA 0,502 yang merupakan MSA terkecil. Dengan demikian keluarkan X1.6 lalu kembali mengulang proses. Kembali terlihat pada component matrix masih terbentuk sebanyak 4 component, yang berarti masih ada indikator yang tidak valid (menjelaskan factor lain selain desain web).

Dengan demikian proses diulang lagi dengan kembali mengeluarkan indikator yang memiliki MSA paling kecil. Terlihat pada bagian anti-images correlation bahwa indikator X1.4 memiliki MSA 0,515 yang merupakan MSA terkecil. Dengan demikian keluarkan X1.4 Terlihat pada tabel component matrix, masih terbentuk sebanyak 4 factor, artinya diantara 10 indikator masih ada indikator yang menjelaskan faktor lain selain desain web, oleh karena itu harus dikeluarkan lagi indikator yang memiliki MSA yang paling kecil (jika MSA yang dibawah 0,5 sudah habis, maka yang dikeluarkan adalah yang memiliki MSA terkecil). Terlihat pada bagian anti-images correlation 
bahwa indikator X1.5 memiliki MSA 0,532 yang merupakan MSA terkecil.

Dengan demikian keluarkan

X1.5 lalu kembali mengulang proses.Kembali terlihat pada component matrix a masih terbentuk sebanyak 3 component, yang berarti masih ada indikator yang tidak valid (menjelaskan factor lain selain desain web). Dengan demikian proses diulang lagi dengan kembali mengeluarkan indikator yang memiliki MSA paling kecil. Terlihat pada bagian anti-images correlation bahwa indikator X1.3 memiliki MSA 0,493 yang merupakan MSA terkecil. Dengan demikian keluarkan X1.3

Kembali terlihat pada component matrix masih terbentuk sebanyak 3 component, yang berarti masih ada indikator yang tidak valid (menjelaskan factor lain selain desain web). Dengan demikian proses diulang lagi dengan kembali mengeluarkan indikator yang memiliki MSA paling kecil. Terlihat pada bagian anti-images correlation bahwa indikator X1.2 memiliki MSA 0,376 yang merupakan MSA terkecil. Dengan demikian keluarkan X1.2

Kembali terlihat pada component matrix a masih terbentuk sebanyak 2 component, yang berarti masih ada indikator yang tidak valid (menjelaskan faktor lain selain desain web). Dengan demikian proses diulang lagi dengan kembali mengeluarkan indikator yang memiliki MSA paling kecil. Terlihat pada bagian anti-images correlation bahwa indikator X1.9 memiliki MSA 0,524 yang merupakan MSA terkecil. Dengan demikian keluarkan X1.9Akhirnya, pada proses ini yang terbentuk hanya sebanyak 1 buah component lihat pada tabel Component Matrix a, yang artinya indikator X1.1, X1.8, X1.11, $\mathrm{X} 1.12$, dan $\mathrm{X} 1.13$ sudah valid dan hanya menjelaskan faktor desain web.

\section{Uji Validitas Variabel X2}

Tabel component matrix pada hasil output SPSS terlihat bahwa terbentuk sebanyak 1 component, sesuai yang diharapkan terbentuk hanya 1 component, artinya dari lima indikator X2.1 s/d X2.5 tersebut semuanya valid dan hanyamenjelaskan faktor keandalan.

\section{Uji validitas variabel daya tanggap $X 3$}

Pada tabel component matrix ${ }^{\mathrm{a}}$ pada hasil output SPSS, terlihat bahwa terbentuk sebanyak 3 component, padahal yang diharapkan terbentuk hanya 1 component, artinya dari tujuh indikator X3.1 s/d X3.7 tersebut ada yang tidak valid. jadi jika indikator-indikator tersebut valid, maka hanya akan membentuk satu faktor yakni daya tanggap, oleh karena itu proses harus diulang dengan mengeluarkan indikatorindikator yang dianggap tidak valid.

Indikator-indikator yang akan dikeluarkan adalah indikator-indikator yang memiliki MSA (measure of sampling adequacy) yang di bawah 0,5, atau jika tidak ada yang di bawah 0,5 maka MSA terkecil dikeluarkan dari analisis selanjutnya dengan memperhatikan tabel anti-images matrices pada output SPSS. Perhatikan pada bagian anti-image correlation, terlihat bahwa indikator X3.5 memiliki MSA= 0,404, dengan demikian indikator tersebut dikeluarkan dari analisis Setelah X3.5 dikeluarkan masih terlihat pada component matrix ${ }^{\mathrm{a}}$ masih terbentuk sebanyak 2 component, yang berarti masih ada indikator yang tidak valid (menjelaskan faktor lain selain daya tanggap). Dengan demikian proses diulang lagi dengan kembali mengeluarkan indikator yang memiliki MSA paling kecil. Terlihat pada bagian anti-images correlation bahwa indikator X3.7 memiliki MSA 0,535 yang merupakan MSA terkecil. Dengan demikian keluarkan X3.7 dari analisis selanjutnya

Terlihat pada tabel component matrix $^{a}$ pada hasil output SPSS, terlihat 
bahwa terbentuk sebanyak 1 component, sesuai yang diharapkan terbentuk hanya 1 component, artinya dari 7 indikator hanya ada 5 indikator yang menjelaskan faktor daya tanggap yaitu X3.1 X3.2 X3.3 X3.4 X3.6 tersebut dan dinyatakan valid.

\section{Uji validitas variabel jaminan $X 4$}

Pada tabel component matrix ${ }^{\mathrm{a}}$ pada hasil output SPSS, terlihat bahwa terbentuk sebanyak 3 component, padahal yang diharapkan terbentuk hanya 1 component, artinya dari tujuh indikator X4.1 s/d X4.7 tersebut ada yang tidak valid. jadi jika indikator-indikator tersebut valid, maka hanya akan membentuk satu faktor yakni jaminan, oleh karena itu proses harus diulang dengan mengeluarkan indikator-indikator yang dianggap tidak valid.

Indikator-indikator yang akan dikeluarkan adalah indikator-indikator yang memiliki MSA (measure of sampling adequacy) yang di bawah 0,5 , atau jika tidak ada yang di bawah 0,5 maka MSA terkecil dikeluarkan dari analisis selanjutnya dengan memperhatikan tabel anti-images matrix pada output SPSS. Perhatikan pada bagian anti-image correlation, terlihat bahwa indikator X4.6 memiliki $\mathrm{MSA}=0,453$, dengan demikian indikator tersebut dikeluarkan dari analisis.

\section{Uji validitas variabel pemesanan X5}

Terlihat tabel component matrix ${ }^{a}$ pada hasil output SPSS, terlihat bahwa terbentuk sebanyak 1 component, sesuai yang diharapkan terbentuk hanya 1 component, artinya dari lima indikator X5.1 s/d X5.5 tersebut semuanya valid dan hanya menjelaskan faktor pemesanan.

\section{Uji validitas variabel niat beli on-line}

Terlihat tabel component matrix ${ }^{\mathrm{a}}$ pada hasil output SPSS, terlihat bahwa sebanyak 1 component, sesuai yang diharapkan terbentuk hanya 1 component, artinya dari lima indikatorY.1 s/d Y.5 tersebut semuanya valid dan hanya menjelaskan faktor niat beli online.

2. Hasil Uji Reliabilitas

Uji reliabilitas

\begin{tabular}{|c|c|c|c|}
\hline Variabel & $\begin{array}{c}\text { Cronbach's } \\
\text { Alpha }\end{array}$ & $\begin{array}{l}\text { Nilai } \\
\text { Kritis }\end{array}$ & Keterangan \\
\hline desain web (X1) & 0.601 & 0.60 & reliabel \\
\hline keandalan (X2) & 0.741 & 0,60 & reliabel \\
\hline daya tanggap (X3) & 0.744 & 0,60 & reliabel \\
\hline jaminan (X4) & 0.752 & 0,60 & reliabel \\
\hline pemesanan (X5) & 0.758 & 0,60 & reliabel \\
\hline niat beli (Y) & 0.747 & 0,60 & reliabel \\
\hline
\end{tabular}

Dari tabel reliabilias diatas dapat di jelaskan bahwa variabel $\mathrm{X} 1$ indikator memiliki nilai cronbach's alpha 0,601 yaitu lebih besar dari 0,60 berdasarkan ketentuan diatas maka indikatorindikator dalam variabel X1 dikatakan reliabel selanjutnya variabel X2 indikator memiliki nilai cronbach's alpha 0,741 yaitu lebih besar dari 0,60 maka dinyatakan reliabel. Variabel X3 yang memiliki cronbach's alpha 0,744 yaitu lebih besar dari 0,60 maka dinyatakan reliabel. Variabel X4 dengan cronbach's alpha 0,752 yaitu lebih besar dari 0,60 maka dinyatakan reliabel. Variabel X5 dengan cronbach's alpha 0,758 yaitu lebih besar dari 0,60 maka dinyatakan reliabel juga selajutnya variabel Y dengan cronbach's alpha 0,747 yaitu lebih besar dari 0,60 maka dinyatakan reliabel artinya dari kelima variabel baik dependen maupun independen semuanya di nyatakan reliabel dan layak untuk digunakan menjadi alat ukur kuesioner dalam penelitian ini

\section{Hasil Uji Regresi Linier Berganda Hasil uji regresi (koefisien regresi)}

\begin{tabular}{|l|l|l|l|l|}
\hline \multicolumn{1}{|c|}{ MODEL } & \multicolumn{1}{|c|}{ B } & \multicolumn{1}{c|}{ Beta } & \multicolumn{1}{c|}{ S } & Sig. \\
\hline (Constant) & $1.429 \mathrm{E}-16$ & & .000 & 1.000 \\
\hline desain web & -.100 & -.100 & -.992 & .324 \\
Keandalan & .269 & .269 & 2.423 & .018 \\
\hline Daya tanggap & .061 & .061 & .585 & .561 \\
\hline Jaminan & .024 & .024 & .235 & .815 \\
\hline pemesanan & .358 & .358 & .3 .215 & .002
\end{tabular}


Berdasarkan analisis data diatas diperoleh persamaan sebagai berikut :

$\mathrm{Y}=1.429 \mathrm{E}-16+-0.100 \mathrm{X} 1+0,269 \mathrm{X} 2$ $+0,061 X 3+0,024 X 4+0,358 X 5$

Dari hasil persamaan regresi linier berganda tersebut, dapat diinterpretasikansebagai berikut :

$\mathrm{a}=1.429 \mathrm{E}-16$ merupakan nilai konstanta, jika nilai $\mathrm{X} 1, \mathrm{X} 2, \mathrm{X} 3, \mathrm{X} 4, \mathrm{X} 5$ dianggap 0 maka akan menurunkan niat beli on-line sebesar 0.000 .

b1 $=-0,100$ artinya variabel desain web berpengaruh negatif terhadap niat beli on-line dan apabila variabel desain web meningkat sebesar 1 satuan, maka niat beli online akan berpengaruh negatif denangan nilai $-0,100$. Seberapa tinggi kenaikan desain web tidak akan mempengaruhi meningkatkan niat beli online.

b2 $=0,269$ artinya variabel keandalan berpengaruh positif terhadap niat beli online dan apabila variabel keandalan meningkat sebesar 1 satuan, maka niat beli online akan meningkat 0,269. Semakin tinggi kenaikan keandalan maka semakin tinggi juga akan mempengaruhi niat beli online

$\mathrm{b} 2=0,061$ artinya variabel daya tanggap berpengaruh positif terhadap niat beli online dan apabila variabel daya tanggap meningkat sebesar 1 satuan, maka niat beli online akan meningkat sebesar 0,061 Semakin tinggi daya tanggapmaka semakin tinggi tingkat niat beli online.

b3 $=0,024$ artinya variabel jaminan berpengaruh positif terhadap niat beli online dan apabila variabel jaminan meningkat sebesar 1 satuan, maka niat beli online akan meningkat sebesar 0,021. Semakin tinggi kenaikan jaminan makan akan semakin tinggi tingkat niat beli online

$\mathrm{b} 4=0,354$ artinya variabel pemesanan berpengaruh positif terhadap niat beli online dan apabila variabel pemesanan meningkat sebesar 1 satuan, maka niat beli online akan meningkat sebesar 0,354 . Semakin tinggi pemesanan maka semakin tinggi tingkat niat beli online

\section{Hasil Uji Parsial (Uji T)}

Tabel 4.4

Hasil uji signifikansi parsial (uji t)

\begin{tabular}{|c|c|}
\hline \multirow{2}{*}{ Variabel } & Hasil Uji \\
\cline { 2 - 2 } & Signifikasi \\
\hline Desain web & 0.324 \\
\hline Keandalan & 0.018 \\
\hline Daya tanggap & 0.561 \\
\hline Jaminan & 0.815 \\
\hline Pemesanan & 0.002 \\
\hline
\end{tabular}

Sumber: data diolah 2015

\section{Variabel Desain Web}

Hasil pengujian dengan SPSS untuk variabel desain web diperoleh nilai $\mathrm{t}$ hitung $=-0.992$ dengan tingkat signifikansi 0.324 . Dengan menggunakan batas signifikansi $(\alpha)=$ 0,05 , maka nilai batas signifikansi $\alpha$ $(0,05)<\operatorname{sig} 0.324$ maka hipotesis di tolak. Hal ini berarti desain web (X1) tidak mempunyai pengaruh terhadap niat beli online $(\mathrm{Y})$.

\section{Variabel Keandalan}

Hasil pengujian dengan SPSS untuk variabel keandalan diperoleh nilai $\mathrm{t}$ hitung $=2.423$ dengan tingkat signifikansi 0.018 Dengan menggunakan batas signifikansi $(\alpha)=$ 0,05 , maka nilai batas signifikansi $\alpha$ $(0,05)>$ sig 0.018 maka hipotesis di terima. Hal ini berarti keandalan (X2) mempunyai pengaruh terhadap niat beli online (Y).

\section{Hasil Uji Simultan (Uji F)}

\section{Tabel 4.5}

Hasil uji signifikansi simultan (uji F)

\begin{tabular}{|l|l|l|l|l|} 
Model & $\begin{array}{c}\text { Sum of } \\
\text { Squares }\end{array}$ & Df & F & Sig. \\
\hline Regression & 22.467 & 5 & 5.960 & $.000^{\mathrm{a}}$ \\
\hline Residual & 53.533 & 71 & & \\
\hline Total & 76.000 & 76 & &
\end{tabular}

Sumber: data diolah 2015 
Berdasarkan hasil uji simultan dari tabel di atas ditunjukkan bahwa $F$ hitung sebesar 5.960 dan pada uji $\mathrm{F}$ di atas didapatkan dengan taraf signifikasi 0,05 (sig $0,000<\alpha \quad 0,05$ ), dapat disimpulkan bahwa faktor desain web (X1), keandalan (X2), daya tanggap (X3) jaminan (X4), pemesanan (X5) bersama-sama memiliki pengaruh yang signifikan terhadap niat beli online (Y).

\section{Hasil Uji Koefisien Determinasi}

Tabel 4.6

Hasil uji regresi (koefisien determinasi)

\begin{tabular}{|r|r|r|}
\hline R Square & $\begin{array}{c}\text { Adjusted R } \\
\text { Square }\end{array}$ & $\begin{array}{c}\text { Std. Error } \\
.296\end{array}$ \\
.246 & .86832359 \\
\hline
\end{tabular}

Sumber: data diolah 2015

Pada tabel diatas dapat dilihat bahwa nilai Adjusted adalah sebesar 0,246. Hal ini dapat diartikan bahwa variabel independent desain web (X1), keandalan (X2), daya tanggap (X3) jaminan (X4), pemesana(X5) dapat menjelaskan variabel dependent niat beli online sebesar $24,6 \%$, sedangkan sisanya diterangkan oleh faktor lain yang tidak diteliti.

\section{Pembahasan}

Pernyataan hipotesis pertama bahwa desain web berpengaruh positif dan signifikan terhadap niat beli online tidak terbukti. Hal ini dapat ditunjukkan dengan nilai signifikansi ( $\mathrm{P}$ Value) sebesar yang lebih beasar dari 0,05 serta nilai koefisien regresi sebesar -0,100. Dapat disimpulkan bahwa desain web berpengaruh negatif tetapi tidak signifikan terhadap niat beli online. Adapun faktor yang menyebabkan desain web tidak berpengaruh terhadap niat beli online adalah kurangnya pengunjung dalam memperhatikan faktor tampilan web dalam mencari informasi barang yang akan dibeli di toko online, pengujung situs web hanya berkunjung berdasarkan kebiasaan seharihari sehingga desain web kurang diperhatikan, biasanya pengujung mencari barang yang diinginkan hanya mencari di google tanpa langsung membuka langsung ke situs web toko online.

Pernyataan hipotesis kedua bahwa keandalan berpengaruh positif dan signifikan terhadap niat beli online terbukti. Hal ini dapat ditunjukkan dengan nilai signifikansi (P Value) sebesar 0,018 yang jauh dibawah 0,05 serta nilai koefisien regresi sebesar 0,269. Hal ini dapat disimpulkan bahwa semakin tinggi keandalan maka akan semakin tinggi juga kenaikan niat beli online.

Pernyataan hipotesis ketiga bahwa daya tanggap berpengaruh positif dan signifikan terhadap niat beli online tidak terbukti. Hal ini dapat ditunjukkan dengan nilai signifikansi ( $\mathrm{P}$ Value) sebesar 0,361 yang jauh diatas 0,05 serta nilai koefisien regresi sebesar 0,061. Dapat disimpulkan bahwa daya tanggap berpengaruh positif tetapi tidak signifikan terhadap niat beli online. Hal itu disebabkan oleh pengunjung belum terlalu percaya dengan informasi informasi pelayanan yang dilihat dan diberikan oleh toko online, biasanya pengunjung atau calon pembeli hanya bisa berinteraksi atau menanyakan informasi yang diinginkan pengunjung dan hanya dapat ditanggapi satupersatu padahal yang bertanya begitu banyak jadi sehingga membutuhkan waktu yang lama untuk mendapat jawaban.

Pernyataan hipotesis keempat bahwa jaminan berpengaruh positif dan signifikan terhadap niat beli online tidak terbukti. Hal ini dapat ditunjukkan dengan nilai signifikansi (P Value) sebesar 0,815 yang jauh diatas 0,05 serta nilai koefisien regresi sebesar 0,024. Dapat disimpulkan bahwa jaminan berpengaruh positif tetapi tidak signifikan terhadap niat beli online. Hal itu disebabkan beberapa faktor salah satunya variabel jaminan dapat di percayai oleh pengunjung ketika mereka melakukan pembeliaan secara langsung sehingga dapat dirasakan karena informasi yang 
tersedia belum bisa meyakinkan untuk mempercayai jaminan yang akan diberikan sama baiknya dengan informasi yang ada, dan juga perbedaan yang mencolok dari situs online dengan jual beli langsung adalah calon pembeli bisa langsung dapat bertatapmuka dengan penjual jadi lebih dapat di percaya dan meyakinkan.

Pernyataan hipotesis kelima bahwa pemesanan berpengaruh positif dan signifikan terhadap niat beli online terbukti. Hal ini dapat ditunjukkan dengan nilai signifikansi (P Value) sebesar 0,002 yang jauh dibawah 0,05 serta nilai koefisien regresi sebesar 0,354 . Hal ini dapat disimpulkan bahwa semakin tinggi pemesanan maka akan semakin tinggi juga kenaikan niat beli online.

Berdasarkan hasil penelitian yang telah dilakukan dapat diketahui pula bahwa Dari variabel desain web (X1), keandalan (X2), daya tanggap (X3) jaminan (X4), pemesanan (X5), variabel desain web dan pemesanan yang paling berpengaruh dominan terhadap niat beli online. Dimana variabel kehandalan dan pemesanan ini mempunyai pengaruh yang positif dan signifikan. Faktor daya tanggap, jaminan, mempunyai pengaruh positif tetapi tidak signifikan. Sedangkan faktor desain web menurut hasil penelitian ini tidak berpengaruh positif dan juga tidak signifikan terhadap niat beli online.

\section{KESIMPULAN DAN SARAN}

\section{Kesimpulan}

Berdasarkan analisis regresi linier berganda, maka dapat dilihat bahwa yang paling berpengaruh terhadap variabel niat beli adalah variabel keandalanserta variable pemesanan, variabel jaminan berpengaruh positif tetapi tidak signifikan, variabel daya tanggap berpengaruh positif tetapi tidak signifikan sedangkan variabel desain web tidak berpengaruh positif dan juga tidak signifikan terhadap niat beli online.
Pada pengujian hipotesis dengan menggunakan uji $F$ (secara bersamasama atau smultan) dapat dijelaskan bahwa kelima variabel yaitu bukti desain web (X1), keandalan (X2), daya tanggap (X3) jaminan (X4), pemesanan (X5) terhadap variabel terikat niat beli online (Y) secara bersamasama berpengaruh terhadap niat beli online.

Nilai koefisien determinasi (R2) yang dihasilkan adalah 0,246. Hal ini berarti sebesar 24,6 persen perubahan variabel niat beli online dapat dijelaskan oleh perubahan variabel desain web (X1), keandalan (X2), daya tanggap (X3) jaminan (X4), pemesanan (X5) secara bersama-sama, sedangkan sisanya sebesar 75,4 persen dijelaskan oleh variabel lain yang tidak terdapat dalam penelitian ini.

\section{Saran}

1. Untuk menigkatkan minat beli online pada tokopedia.com yang harus ditingkatkan dan menjadi fokus utama adalah meberikan pelayanan mengenai pemesanan dari pelanggan yaitu dengan cara memberikan respon yang cepat ketika ada order memastikan barang yang di kirim sama dengan yang diinginkan dan sesuai apa yang ditampilkan di web, proses pengiriman yang baik dengan menjaga keamanan barang, kerapian dalam pengemasan, kepastian barang akan sampai ke konsumen, memberikan ucapan terimakasih ketika barang udah sampai pada pelanggan,selanjutnya yang harus diperhatikan adalah mengenai keandalan salah satunya dengan membuat semudah mungkin proses pembayaran dalam teransaksi jual beli online dan menyediakan nomor khusus untuk komplain pelanggan atau yang mau bertanya mengenai tokopedia.com atau spesifikasi produk yang di tawarkan, menjamin keamanan transaksi dan tak kalah pentingnya yang harus 
ditingkatkan adalah mengenai desain web yang mudah di operasikan dan menarik serta prosedur-prosedur pemesanan, pembatalan, dan pembayaran ditampilkan secara rinci di dalam web. Sehingga calon pelanggan yang akan melakukan pembelian dapat mencari informasi denga mudah dan menambah keyakinan akan keputusan pembelian pada tokopedia.com. untuk mendukung kesuksesan dan menambah jumlah pembeli pada tokopedia.com tak lupa faktor pelayanan juga harus ditingkatkan mengingat semakin banyaknya situs online yang berkembang di Indonesia sehingga persaingan tidak hanya terjadi pada faktor fisik yang dapat dilihat oleh mata tetapi juga faktor pelayanan yang baik.

2. Penelitian yang akan datang

a. Diharapkan penelitian yang akan datang, sampel yang digunakan lebih banyak sehingga hasil analisis dari penelitian yang didapatkan akan lebih akurat.

b. Melakukan penelitian dengan aspek yang sama dengan menambahkan variabel yang menyangkut aspek tersebut untuk lebih mengetahui variabel-variabel lain yang mempengaruhi niat beli online, diluar variabel yang telah diteliti penulis. Dan dapat lebih meningkatkan penelitian bukan hanya niat beli online akan tetapi sudah meningkat ke keputusan pembelian atau kepuasan pelanggan sehingga dapat membantu kesuksesan dalam dunia pemasaran khususnya tentang online shop.

\section{DAFTAR PUSTAKA}

Barkatullah, Abdul Halaim dan Prasetyo Teguh, 2005, Bisnis E-commerce Studi Sistem Hukum dan
Keamanan di Indonesia, Yogyakarta: Pustaka Pelajar

Ferdinand, Augusty. 2006. Metode Penelitian Manajemen. Badan Penerbit Universitas Diponegoro. Semarang.

Ghozali, H. Imam. 2011. Aplikasi Analisis Multi Variate dengan Program IMB SPSS 19. Semarang: BP UNDIP

Hamdiana dan Indriyani, Evi. 2005, Sistem Informasi Manajemen. Yogyakarta: Graha Ilmu.

Mary Long and Charles McMellon, 2004, Exploring the determinants of retail service quality on the Internet, Journal of Services Marketing, Volume 18.

Suryani, Tutik, 2013, Perilaku Konsumen Di Era Internet, Edisi Pertama, Yogyakarta, Graha Ilmu

Suyanto, M. 2003. Strategi Periklanan Pada E-Commerce Perusahaan Top Dunia, Edisi 1, Yogyakarta, Andi.

Sugiyono. 2013. Metode Penelitian Kuantitatif, Kualitatif Dan R \& D, Bandung, Alfabeta 